\title{
Differential Expression of $3 \beta$-Hydroxysteroid Dehydrogenase mRNA in Rat Testes Exposed to Endocrine Disruptors
}

\author{
Hwan-Hee KIM ${ }^{1)}$, Dong-Hoon KWAK ${ }^{1)}$, Jung-Min YON ${ }^{1}$, In-Jeoung BAEK ${ }^{1}$, \\ Se-Ra LEE ${ }^{1)}$, Jeung-Eun LEE'), Sang-Soep NAHM ${ }^{1)}$, Jae-Hwang JEONG ${ }^{2)}$, \\ Beom Jun LEE ${ }^{1)}$, Young Won YUN ${ }^{1)}$ and Sang-Yoon NAM ${ }^{1)}$ \\ ${ }^{1)}$ College of Veterinary Medicine and Research Institute of Veterinary Medicine, Chungbuk \\ National University, Cheongju 361-763 and ${ }^{2)}$ Department of Bio-industry, Seowon University, \\ Cheongju 361-742, Korea
}

\begin{abstract}
Expression of $3 \beta$-hydroxysteroid dehydrogenase $(3 \beta-H S D)$ is mainly found in the Leydig cells from which steroid hormones are biosynthesized in the testes. To investigate whether endocrine disruptors affect the microenvironment of the testes, the mRNA expression of $3 \beta-H S D$ as a molecular marker for androgen biosynthesis was analyzed in rat testes exposed to several endocrine disruptors using a reverse transcription-polymerase chain reaction technique. Testosterone [50, 200 and 1,000 $\mu \mathrm{g} / \mathrm{kg}$ body weight (BW)], flutamide $(1,5$ and $25 \mathrm{mg} / \mathrm{kg} \mathrm{BW})$, ketoconazole $(0.2,1,5$ and $25 \mathrm{mg} / \mathrm{kg}$ BW), diethylhexyl phthalate (10, 50 and $250 \mathrm{mg} / \mathrm{kg} \mathrm{BW})$, nonylphenol (10, 50, 100 and $250 \mathrm{mg} / \mathrm{kg}$ BW), octylphenol (10, 50 and $250 \mathrm{mg} / \mathrm{kg} \mathrm{BW})$, and diethylstilbestrol (10, 20 and $40 \mu \mathrm{g} / \mathrm{kg}$ BW) were orally administered to 4 -week-old Sprague-Dawley rats for 3 weeks daily. Although testosterone at a low dose (50 $\mu \mathrm{g} / \mathrm{kg} /$ day) increased the expression of $3 \beta-H S D$ mRNA, it was significantly decreased in the rats treated with 200 or $1,000 \mu \mathrm{g} / \mathrm{kg} /$ day testosterone compared with the control group $(\mathrm{P}<0.05)$. Furthermore, ketoconazole, diethylhexyl phthalate, nonylphenol, octylphenol and diethylstilbestrol caused significant downregulation of $3 \beta-H S D$ mRNA in the testes at all doses $(\mathrm{P}<0.05)$. However, flutamide remarkably increased the level of $3 \beta-H S D$ mRNA in the testes $(\mathrm{P}<0.05)$. These results suggest that endocrine disruptors may influence androgen biosynthesis in the testes by alteration of $3 \beta-H S D$ mRNA expression.

Key words: $3 \beta$-hydroxysteroid dehydrogenase $(3 \beta-H S D)$, Endocrine disruptors, Leydig cells, Rat, Testis
\end{abstract}

(J. Reprod. Dev. 53: 465-471, 2007)

S teroid hormones are synthesized from cholesterol in the adrenal cortex and gonads in response to pituitary tropic hormones such as adrenocorticotropic hormone (ACTH), follicle stimulating hormone (FSH) and luteinizing hormone (LH). Sex steroids induce and maintain secondary sexual characteristics and are essential for reproduction [1].

Accepted for publication: December 2, 2006

Published online: January 17, 2007

Correspondence: S.Y. Nam (e-mail: synam@cbu.ac.kr)
Development of the mature adult testis is initiated by the final generation of Leydig cells, which starts just before pubertal development in the male rat. The number and size of Leydig cells increases in conjunction with increased Leydig cell steroidogenesis [2]. Most studies of steroidogenesis during pubertal development have focused on the declining expression and activity of a steroid metabolizing enzyme, $3 \beta$-hydroxysteroid dehydrogenase/isomerase $(3 \beta-H S D)$, in Leydig cells which converts testosterone to biologically 
active compounds [3]. Little data exist concerning the tissue localization and temporal pattern of steroidogenic enzyme expression in the biosynthetic pathway to testosterone in the rat testis. A key enzyme in steroidogenesis is $3 \beta$-HSD, which is often used as a histochemical marker for Leydig cells. It converts pregnenolone to progesterone, an obligatory intermediate in testosterone biosynthesis [4]. Testosterone biosynthesis is also dependent on $17 \alpha-$ hydroxylase $/ 17,20$ desmolase $\left(\mathrm{P}_{450} \mathrm{c} 17\right)$, a single catalytic protein in the rat testis [5].

Endocrine disruptors can disturb development of the endocrine system and organs that respond to endocrine signals in organisms indirectly exposed to them during prenatal and/or early postnatal life [6]. Many studies have reported the detrimental effects of endocrine disruptors. For example, antiandrogenic endocrine disruptors inhibit spermatogenesis with additional antigonadotropic properties. Anti-androgens, such as flutamide (FM), have a slight and transient influence on spermatogenesis at most. FM blocks negative feedback of testosterone on the hypothalamopituitary axis [7] and inhibits production of the ventral prostate [8]. Ketoconazole (KC) decreases epididymal sperm number and motility, increases the proportion of abnormal sperm [9], and reduces steroidogenesis by inhibiting the cytochrome P-450 enzymes [10]. DeFelice et al. [11] reported that KC induced gynecomastia in male rats. Diethylhexyl phalate (DEHP) treatment produces developmental and/or reproductive toxicity in a wide range of mammalian species with a period of susceptibility extending from the fetal to pubertal stages of life and induces reproductive tract malformations in androgen-dependent tissues in male rat offspring [12]. Octylphenol (OP) exerts estrogenic action to suppress LH, FSH and testosterone secretion and enhance prolactin secretion. OP greatly reduces sperm number and adversely influences the size of the rat testis [13]. Diethylstilbestrol (DES) induces a reduction in testis formation and abnormal semen, resulting in infertility in rats [14, 15].

In the present study, we investigated the effects of various endocrine disruptors on steroidogenesis by analyzing the $3 \beta$-HSD mRNA expression pattern as a biomarker for Leydig cells in the testes of rats.

\section{Materials and Methods}

\section{Animals and chemical treatment}

Four-week-old male Sprague-Dawley rats were purchased from Samtaco (Gyeonggido, Korea). The animals ( $n=10 /$ group) were housed under standard laboratory conditions that included a 12-h light/dark cycle, temperature of $21 \pm 2 \mathrm{C}$, relative humidity of $50 \pm 10 \%$ and were fed standard rat pellet and water ad libitum. All experiments were approved and carried out according to the "Guide for care and use of animals" (Chungbuk National University Animal Care Committee according to NIH \#86-23). The endocrine disruptors, testosterone propionate [T; 50, 200 and 1,000 $\mu \mathrm{g} / \mathrm{kg}$ body weight (BW)], $\mathrm{KC}(0.2,1,5$ and $25 \mathrm{mg} / \mathrm{kg}$ BW), DEHP (10, 50 and $250 \mathrm{mg} / \mathrm{kg}$ BW), OP $(10,50$ and $250 \mathrm{mg} / \mathrm{kg} \mathrm{BW})$, DES (10, 20 and $40 \mu \mathrm{g} / \mathrm{kg}$ BW), NP (10, 50, 100 and $250 \mathrm{mg} / \mathrm{kg} \mathrm{BW})$, and FM (1, 5 and $25 \mathrm{mg} / \mathrm{kg} \mathrm{BW})$, were orally administered to the rats daily for 3 weeks. The control group was treated with corn oil. The rats were euthanized at 7 weeks of age under pentobarbital anesthesia, and then their testes were removed. The testes were frozen using liquid nitrogen and stored at $-70 \mathrm{C}$ until use. All chemicals were obtained from SigmaAldrich (St. Louis, MO, USA).

\section{Total RNA extraction and reverse transcription- polymerase chain reaction (PCR)}

Total RNA was extracted from testes using TRIzol reagent (Life Technologies, Gaithersburg, MD, USA) according to the manufacturer's instructions. The RNA pellet obtained in the final step was dissolved in $50 \mu$ of sterile diethylpyrocarbonate (DEPC)-treated water, and its concentration was determined using a UV spectrophotometer at $260 \mathrm{~nm}$. RNA was kept in DEPC-treated water at $-70 \mathrm{C}$ until use. Reverse transcription of mRNA and amplification of cDNA were performed using a Peltier Thermal Cycler (MJ Research, Waltham, MA, USA).

A cDNA synthesis kit (Roche Diagnostics, Mannheim, Germany) was used to generate cDNA from $1.0 \mu \mathrm{g}$ total RNA according to the manufacture's instructions. The following primer sets were used to amplify $3 \beta$-HSD (GenBank accession number GI388200) and GAPDH [16] as an internal control.

$3 \beta$-HSD forward: 5'-TCTACTGCAGCACAGTTGAC-3' 

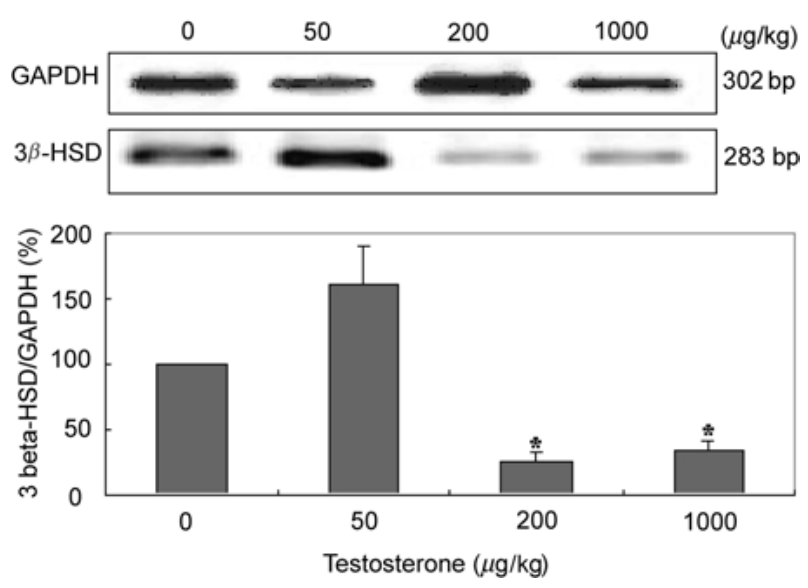

Fig. 1. Reverse transcription-polymerase chain reaction (RTPCR) experiments showing the expression of $3 \beta$ testes of testosterone-treated rats. GAPDH: the intrinsic control. Values represent means $\pm S D(n=10)$. ${ }^{*} \mathrm{P}<0.05$ : compared to the controls. hydroxysteroid dehydrogenase $(3 \beta$-HSD) mRNA in the
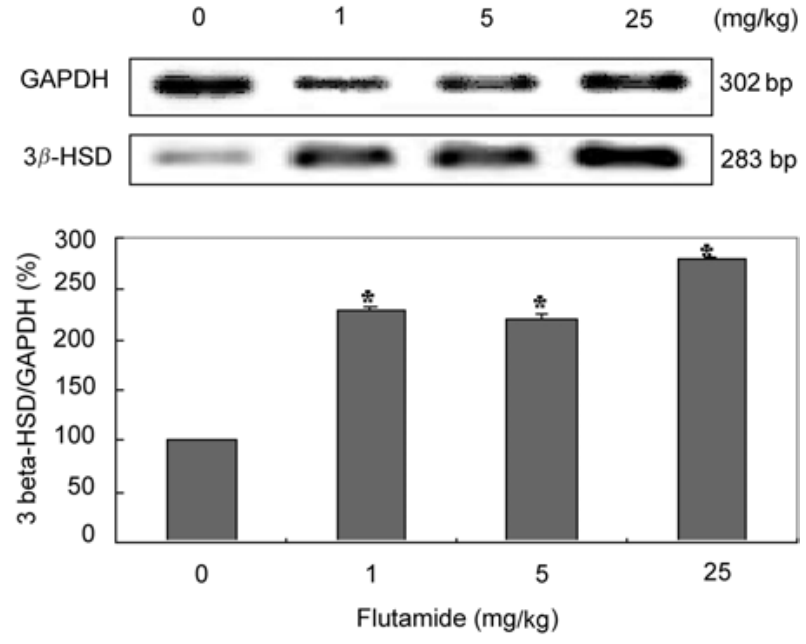

Fig. 2. The mRNA expression of $3 \beta$-hydroxysteroid dehydrogenase $(3 \beta-H S D)$ in the testes of rats exposed to flutamide for 3 weeks. GAPDH: the intrinsic control. Values represent means \pm SD $(n=10)$. ${ }^{*} \mathrm{P}<0.05$ : compared to the controls.

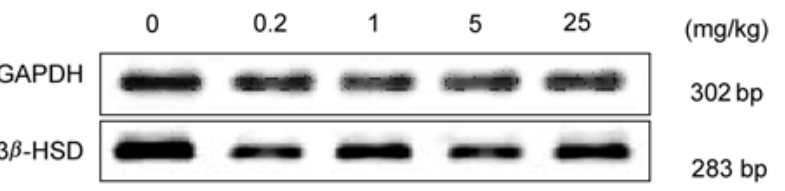

$3 \beta$-HSD reverse: 5'-ATACCCTTATTTTTGAGGGC-3'

GAPDH forward: 5'-AACCGGATTTGGTCGTATTGG-3'

GAPDH reverse: 5'-AGCCTTCTCCAATGGTGGTGAAGAC-3'

The PCR products were run on $2 \%$ agarose gel in Tris-borate-EDTA buffer. The expected PCR product sizes of $3 \beta$-HSD and GAPDH were 283 and $302 \mathrm{bp}$, respectively. The relative intensities of the $3 \beta$-HSD bands were normalized to the corresponding GAPDH band intensities.

\section{Statistical analysis}

The data were analyzed by analysis of variance and Duncan's test, as a post-hoc analysis, using the SPSS software. Statistical significance was set at $\mathrm{P}=$ 0.05 . All data were presented as means \pm SD.

\section{Results}

The detrimental effects of endocrine disruptors in the testes of rats were studied through analysis of $3 \beta$-HSD mRNA expression as a biomarker. Treatment with endocrine disruptors resulted in a general decrease in $3 \beta-H S D$ expression, except for treatment with FM. A dose of $50 \mu \mathrm{g} / \mathrm{kg} /$ day T increased the expression of $3 \beta$-HSD mRNA.
However, expression of $3 \beta$-HSD mRNA was significantly $(\mathrm{P}<0.05)$ decreased in the rats treated with 200 or $1,000 \mu \mathrm{g} / \mathrm{kg} / \mathrm{day} \mathrm{T}(20$ and $30 \%$, respectively) compared with the control group (Fig. 1). Furthermore, while the levels of $3 \beta-H S D$ mRNA significantly $(\mathrm{P}<0.05)$ increased to $220-280 \%$ in the FM-treated group compared with the control group (Fig. 2), KC caused downregulation of $3 \beta-H S D$ 

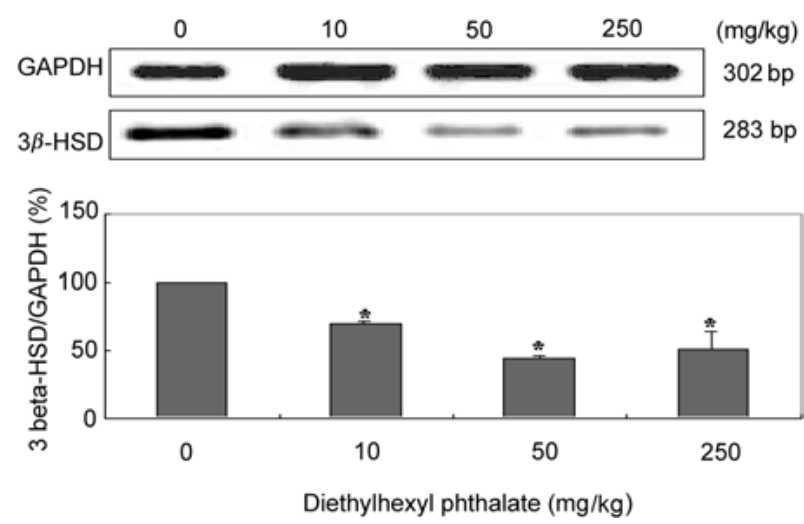

Fig. 4. RT-PCR analysis showing mRNA expression of $3 \beta$ hydroxysteroid dehydrogenase $(3 \beta-H S D)$ in diethylhexyl phthalate-treated testes. GAPDH: the intrinsic control. Values represent means $\pm S D(n=10)$. ${ }^{*} \mathrm{P}<0.05$ : compared to the controls.
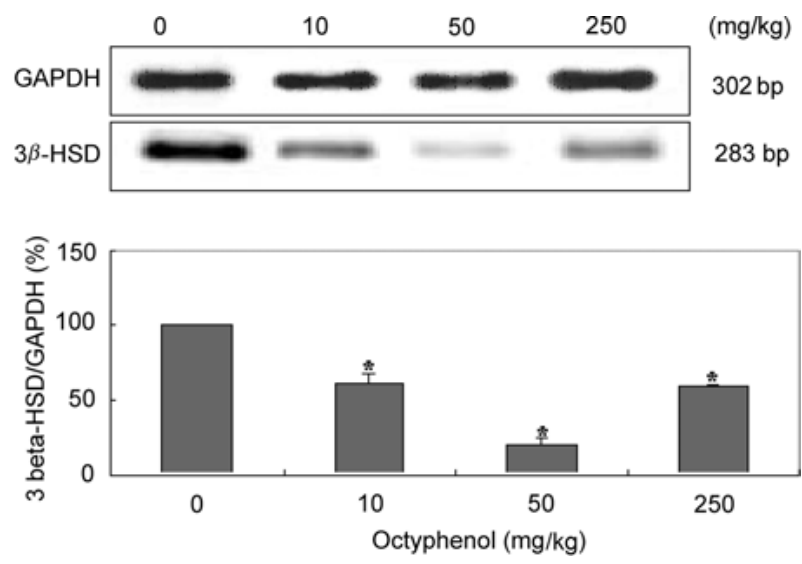

Fig. 5. Photograph of the $3 \beta$-hydroxysteroid dehydrogenase $(3 \beta-H S D)$ mRNA expression in rat testes using RTPCR. Rats were exposed to octylphenol for 3 weeks. GAPDH: the intrinsic control. Values represent means $\pm S D(n=10)$. ${ }^{*} P<0.05$ : compared to the controls.

mRNA to less than $70 \%$ of the control group level (Fig. 3). In the case of DEHP, $3 \beta$-HSD mRNA was significantly $(\mathrm{P}<0.05)$ decreased to $48-70 \%$ of the control level (Fig. 4). OP inhibited 3 $\beta$-HSD mRNA expression in the testes at all doses. In particular, the signal was remarkably decreased to $27 \%$ of the control level in the $50 \mathrm{mg} / \mathrm{kg}$ OP group $(\mathrm{P}<0.05$; Fig. 5). In the NP-treated rats, $3 \beta$-HSD mRNA expression was significantly $(\mathrm{P}<0.05)$ reduced to $40-50 \%$ of the control level (Fig. 6). The testicular
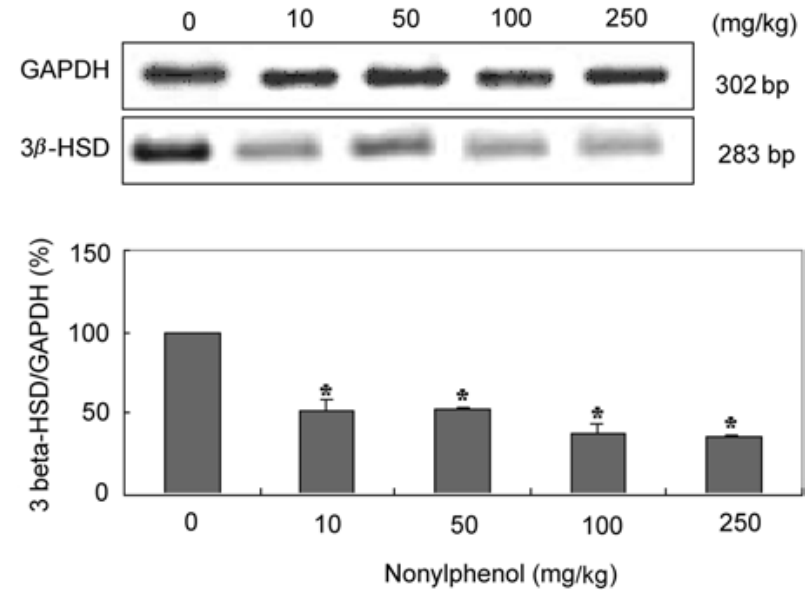

Fig. 6. RT-PCR indicates the expression of $3 \beta$-hydroxysteroid dehydrogenase ( $3 \beta$-HSD) mRNA in nonylphenoltreated testes. GAPDH: the intrinsic control. Values represent means $\pm S D(n=10)$. ${ }^{*} \mathrm{P}<0.05$ : compared to the controls.
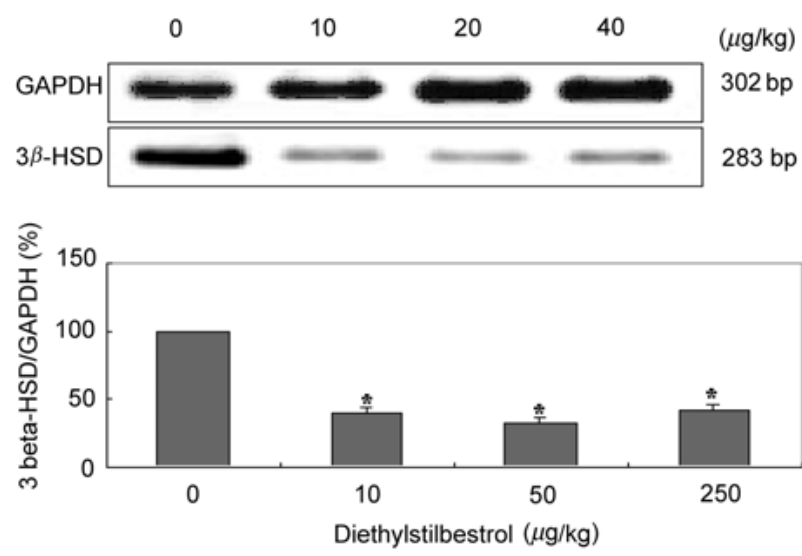

Fig. 7. Expression pattern of $3 \beta$-hydroxysteroid dehydrogenase $(3 \beta-H S D)$ mRNA in testes exposed to diethylstilbestrol as measured by RT-PCR. GAPDH: the intrinsic control. Values represent means \pm SD $(n=10) .{ }^{*} \mathrm{P}<0.05$ : compared to the controls.

level of $3 \beta$-HSD mRNA in the rats exposed to various concentrations $(10,20$, and $40 \mu \mathrm{g} / \mathrm{kg} /$ day $)$ of DES was significantly $(\mathrm{P}<0.05)$ lower $(35-42 \%)$ than that of the control group (Fig. 7).

\section{Discussion}

We investigated the changes of $3 \beta-H S D$ mRNA expression in the rat testes using RT-PCR after 
treatments with endocrine disruptors, including $\mathrm{T}$, FM, KC, DEHP, NP, OP and DES. Our results demonstrate that endocrine disruptors have different effects on $3 \beta-H S D$ mRNA expression in the testes.

The mRNA of $3 \beta-H S D$ is known as a maker of steroidogenesis in Leydig cells. $\mathrm{T}$, the principal circulating androgen in the adult male, is essential for maintenance of spermatogenesis and expression of secondary sex characteristics. Production of $\mathrm{T}$ is regulated in the testis by a negative feedback system [17].

Our study showed that high doses of T (200 and $1,000 \mu \mathrm{g} / \mathrm{kg} /$ day) decreased $3 \beta-H S D$ mRNA expression, but that a low dose of $\mathrm{T}$ ( $50 \mu \mathrm{g} / \mathrm{kg} /$ day) increased the $3 \beta-H S D$ mRNA level compared with the controls. This phenomenon could be explained by the fact that expression of $3 \beta-H S D$ is under control of negative feedback mechanism that is regulated by testosterone.

FM is an anti-androgenic compound and a nonsteroidal androgen receptor (AR) antagonist that interferes with endogenous androgen binding to ARs in target organs [18]. FM blocks the negative feedback of $\mathrm{T}$ in the hypothalamus and pituitary and induces overexpression of steroidogenic enzyme in the testis by increased T production [7]. In our study, the expression of $3 \beta-H S D$ mRNA was significantly increased in all the FM-treated groups compared with the control group. These results suggest that the negative feedback of T was blocked by FM binding to the AR in the testis.

The KC-treated groups showed a decreased trend in the expression of $3 \beta$-HSD mRNA compared with the controls. KC, a broad-spectrum imidazole antimycotic agent, interferes with the cytochrome P-450 enzyme system in several organs [19]. It inhibits microsomal steroidogenesis in Leydig cells [20]. Therefore, our results suggest that $\mathrm{KC}$ may inhibit $\mathrm{T}$ production in the testis by the blocking $3 \beta$-HSD biosynthesis via inhibition of cytochrome P450 enzyme activity.

The DEHP treatment decreased $3 \beta-H S D$ mRNA expression in the testes compared with the controls. This is in agreement with a previous report showing that DEHP has been recognized as an endocrine disruptor because it induces adverse effects in androgen responsive tissue following perinatal exposure of male rats [12]. It also reduces testicular T production in vivo and T levels in the testis [21]. Other studies have reported that exposure of rats to DEHP (200 mg/ kg/day) causes various effects, including a $77 \%$ decrease in the activity of the steroidogenesis enzyme $17 \beta$ hydroxysteroid dehydrogenase, a $50 \%$ reduction in $\mathrm{T}$ production in Leydig cells [22], enhanced testosterone $5 \alpha$-reductase (T5 $\alpha-\mathrm{R})$ activity in the testis [23], and reduced epididymal sperm density and motility [24].

$\mathrm{OP}$ is an alkylphenolic compound formed as a metabolite of some nonionic surfactants used widely in such things as industrial detergents, plastic and petrol additives and dispensers for insecticides [25]. It has been shown to reduce the expression of cytochrome P450 17 $\alpha$-hydroxylase/ C17-20 lyase in fetal Leydig cells [26] and to decrease the expression of steroidogenesis factor-1 (SF-1) mRNA in the fetal testis [27]. It has also been found to be weakly estrogenic in vitro, to bind to the estrogen receptor (ER), to stimulate estrogendependent growth of breast cancer cells and gene expression in vitro [28], and to decrease prenatal $\mathrm{T}$ production in the testis. In our study, treatment with OP $(10,50,100$ and $250 \mathrm{mg} / \mathrm{kg} / \mathrm{day})$ significantly decreased $3 \beta-H S D$ mRNA expression. A significantly decreased trend of $3 \beta-H S D$ mRNA expression was also shown in all the NP-treated groups $(10,50,100$ and $250 \mathrm{mg} / \mathrm{kg} /$ day $)$. NP is a weakly estrogenic compound generated from alkylphenol ethoxylates that is widely used in the production of plastics, textiles, and agricultural chemicals and in household applications and cosmetics $[25,29,30]$. Several studies have reported the adverse effects of NP on development of the male reproductive tract when animals are parentally exposed to NP $[13,31]$. Therefore, our results suggest that the inhibition of $3 \beta-H S D$ mRNA production by NP and OP may be due to functional defects in Leydig cells such as a reduction in cytochrome P450 enzyme production.

DES is an anti-androgenic compound that has been used to prevent miscarriage and other pregnancy complications. It has been reported to reduce the activity of testicular P450c17 enzyme, $17 \alpha$-hydroxylase, and SF-1 in 17.5-day-old fetuses [32-34]. In this study, treatment with DES inhibited $3 \beta-H S D$ mRNA expression in the testis. Our results suggest that DES probably inhibited steroidogenesis via blockage of $3 \beta$-HSD and that it may reduce $\mathrm{T}$ production in the testis.

In conclusion, several endocrine disruptors changed the expression pattern of $3 \beta-H S D$ mRNA 
in the testes as determined by RT-PCR. These results suggest that endocrine disruptors may influence androgen biosynthesis in the testis through an abnormal change in $3 \beta-H S D$ mRNA expression.

\section{Acknowledgements}

This work was supported by the Korea Research Foundation Grant funded by the Korea Government [MOEHRD, Basic Research Promotion Fund (KRF-2004-005-E00168 and KRF-2005-005J15002)].

\section{References}

1. Miao J, Chan KW, Chen GG, Chun SY, Xia NS, Chan JY, Panesar NS. Blocking BRE expression in Leydig cells inhibits steroidogenesis by downregulating 3beta-hydroxysteroid dehydrogenase. $J$ Endocrinol 2005; 185: 507-517.

2. Maddocks S, Setchell BP. The physiology of the endocrine testis. Oxf Rev Reprod Biol 1988; 10: 53-123.

3. Ge RS, Hardy MP. Variation in the end products of androgen biosynthesis and metabolism during postnatal differentiation of rat Leydig cells. Endocrinol 1998; 139: 3787-3795.

4. Lorence MC, Naville D, Graham-Lorence SE, Mack SO, Murry BA, Trant JM, Mason JI. 3 betahydroxysteroid dehydrogenase/delta5-4 isomerase expression in rat and characterization of the testis isoform. Mol Cell Endocrinol 1991; 80: 21-31.

5. Mack SO, Garrett WM, Guthrie HD. Absence of correlation between in situ expression of cytochrome P450 17 $\alpha$ hydroxylase/lase and $3 \beta$ hydroxysteroid dehydrogenase $/ \Delta 5-4$ isomerase messenger ribonucleic acids and steroidogenesis during pubertal development in the rat testis. $J$ Steroid Biochem Mol Biol 2000; 73: 19-28.

6. Colborn T, Saal FS, Soto AM. Developmental effects of endocrine disrupting chemicals in wildlife and humans. Environ Health Perspect 1993; 101: 378384.

7. Viguier-Martinez MC, Hochereau de Reviers MT, Perreau C. Effects of flutamide or of supplementation with testosterone in prepubertal male rats prenatally treated with busulfan. Acta Endocrinol 1985; 9: 550-557.

8. Marchetti B, Labrie F. Characteristics of flutamide action on prqostatic and testicular functions in the rat. J Steroid Biochem 1988; 29: 691-698.

9. Vawda AO, Davies AG. An investigation into the effects of ketoconazole in testicular function in Wistar rats. Acta Endocrinol 1986; 111: 246-251.

10. Heckman WR, Kane BR, Pakyz RE, Cosentino MJ The effect of ketoconazole in endocrine and reproductive parameters in male mice and rats. $J$ Androl 1992; 13: 191-193.

11. DeFellce R, Johnson DG, Galgiani JN. Gynecomastia with ketoconazole. Antimicrob Agents Chemother 1981; 19: 1073-1074.
12. Parks LG, Ostby JS, Lambright CR, Abbott BD, Klinefelter GR, Barlow NJ, Gray LE Jr. The plasticizer diethylhexyl phthalate induces maformations by decreasing fetal testosterone synthesis during sexual differentiation in the male rat. Toxicol Sci 2000; 58: 339-349.

13. Bookfor FR, Blake CA. Chronic administration of 4tert-octylphenol to adult male rats cause shrinkage of the testes and male accessory organs, disrupts spermatogenesis and increases the incidence of deformities. Biol Reprod 1997; 57: 267-277.

14. Gill WB, Schumacher GFB, Bibbo M, Straus FH Jr, Schoenberg HW. Association of diethylstilbesterol exposure in utero with cryptorchidism, testicular hypoplasia and semen abnormalities. J Urol 1979; 122: 36-39.

15. McLachlan J, Newhold R, Bullock B. Reproductive tract lesions in male mice exposed prenatally to diethylstilbesterol. Science 1975; 190: 991-992.

16. Tso JY, Sun XH, Kao TH, Beece KS, Wu R. Isolation and characterization of rat and human glyceraldehyde-3-phosphate dehydrogenase cDNAs: Genomic complexity and molecular evolution of the gene. Nucleic Acids Res 1985; 13: 2485-2502.

17. Botte MC, Ladefoged O, Hass U, Vinggaard AM. Steroidogenesis in fetal male rat is reduced by DEHP and DINP, but endocrine effects of DEHP are not modulated by DEHP in fetal, prepubertal and adult male rats. Reprod Toxicol 2004; 18: 53-61.

18. Simard J, Luthy I, Guay J, Belanger A, Labrie F. Characteristics of interaction of the antiandrogen flutamide with the androgen receptor in various target tissues. Mol Cell Endorinol 2001; 44: 261-270.

19. Miossec P, Archambeaud-Mouveroux F, Teissier MP. Inhibition of steroidogenesis by ketoconazole: Therapeutic uses. Ann Endorinol 1997; 58: 494-502.

20. Albertson BD, Frederick KL, Maronian NC, Feuillan P, Schorer S, Dunn JF, Loriaux DL. The effect of ketoconazole on steroidogenesis: I. Leydig cell enzyme activity in vitro. Res Commun Chem Pathol Pharmacol 1988; 61: 17-26.

21. Borch J, Ladefoged O, Hass U, Vinggaard AM. Steroidogenesis in fetal male rats is reduced by DEHP and DINP, but endocrine effects of DEHP are not modulated by DEHA in fetal, prepubertal and 
adult male rats. Reprod Toxicol 2004; 18: 53-61.

22. Akingbemi BT, Youker RT, Scottas CM, Ge R, Katz E, Klinefelter GR, Ziekin BR, Hardy MP. Modulation of rat Leydig cell steroidogenesis function by di(2-rhtylhexyl)phthalate. Biol Reprod 2001; 65: 1252-1259.

23. Kim HS, Saito K, Ishizuka M, Kazusaka A, Fujita S. Short period exposure to di-(2-ethylhexyl) phthalate regulates testosterone metabolism in testis of prepubertal rats. Arch Toxicol 2003; 77: 446-451.

24. Agarwal DK, Eustis S, Lamb JC $4^{\text {th }}$, Reel JR, Kluwe WM. Effects of di(2-ethylhexyl) phthalate on the gonadal pathophysiology, sperm morphology, and reproductive performance of male rats. Envrion Health Perspect 1986; 65: 343-350.

25. Naylor CG, Mierure JP, Weeks JA, Castaldi FJ, Romano RR. Alkylphenol ethoxylates in the environment. J Am Oil chemists Soc 1992; 69: 695-703.

26. Majdic G, Sharpe RM, O'Shaughnessy PJ, Saunders PTK. Expression of cytochrome P450 17alpha-hydroxylase/C17-20-lyase in fetal testis is reduced by maternal exposure to exogenous estrogens. Endocrinol 1996; 137: 1063-1070.

27. Majdic G, Sharpe RM, Saunders PT. Material oestrogen/xenoestrogen exposure alters expression of steroidogenic factor-1 (SF-1/Ad4BP) in the fetal rat testis. Mol Cell Endocrinol 1997; 127: 91-98.

28. White R, Jobling S, Hoare SA, Sumpter JP, Parker MG. Environmentally persistent alkylphenolic compounds are estrogenic. Endocrinology 1994; 135:
$175-182$.

29. Odum J, Ashby J. Neonatal exposure of male rats to nonylphenol has no effect on the reproductive tract. Toxicol Sci 2000; 56: 400-404.

30. Nimrod AC, Benson WH. Environmental estrogenic effects of alkylphenol ethoxylates. Crit Rev Toxicol 1996; 26: 335-364.

31. Sharpe RM, Fisher JS, Millar MM, Jobling S, Sumpter JP. Gestational and lactational exposure of rat to xenoestergens results in reduced testicular size and sperm production. Environ Health Perspect 1995; 103: 1136-1143.

32. Bartke A, Williams KI, Dalterio S. Effects of estrogens on testicular testosterone production in vitro. Biol Reprod 1977; 17: 645-649.

33. Majdic G, Saunders PT, Teerds KJ. Immunoexpression of the steroidogenic enzymes 3-beta hydroxysteroid dehydrogenase and 17 alphahydroxylase, $\mathrm{C} 17,20$ lyase and the receptor for luteinizing hormone $(\mathrm{LH})$ in the fetal rat testis suggest that the onset of Leydig cell steroid production is independent of LH action. Biol Reprod 1998; 58: 520-525.

34. Goyal HO, Braden TD, Mansour M, Williams CS, Kamaleldin A, Srivastava KK. Diethylstilbesteroltreated adult rats with altered epididymal sperm numbers and sperm motility parameters, but without alterations in sperm production and sperm morphology. Biol Reprod 2001; 64: 927-934. 